\title{
Illocution on Speech Acts of Foreign Students in Indonesian Learning
}

\author{
Latifah Tri Budiasih"; Andayani; Muhammad Rohmadi \\ Sebelas Maret University, Jl. Ir. Sutami No.36A, Jebres, Kota Surakarta, Jawa Tengah, Post Code 57126, Indonesia
}

\begin{abstract}
A B S T R A C T
This research discusses illocution on speech acts of foreign students in Indonesian Language learning. Illocution is a speech that shows the state of language relating to the situation in general and aims to express something from the speaker to the partner. This research aims to describe the forms of illocution done by the Indonesian Language students. This is a qualitative study. Observation, interviews, and documentation methods are used to collect data. The data are the utterances containing illocutionary force (assertive, declaration, directives, commissive, and expressive) in learning activities. The data source in this research is the speech acts of a foreign student in Indonesian Language learning.
\end{abstract}

A R T I C L E I N F O

\author{
Paper type: \\ Research Article \\ Article history: \\ Received 26 August 2017 \\ Revised 19 February 2018 \\ Accepted 13 August 2018 \\ Keywords: \\ - illocution, \\ - speech acts, \\ - illocutionary force types
}

\section{Introduction}

Humans are social beings who at all times and every time always need others. Given these traits, language can bridge humans to interact each other. In interacting, people use various media and one of them is language. Through language, people can exchange ideas, stories and even information that may be needed. In other words, language is a major component of interaction. In addition to understanding how the context of speech is used, people must also understand whether a proper utterance used to convey something to be conveyed without any misunderstandings between speakers with partners said.

The importance of understanding the various aspects of speech acts is a must, so that communication can be well established. The existence of understanding between the speaker and the listener is a very important thing that will indicate that the communication is running smoothly. Pragmatics is a branch of linguistics that studies the use of languages that integrate to grammar which consists of phonology, morphology, syntax, and semantics (Leech, 2011). In contrast to Leech, Yule (1996) defined Pragmatics into four scopes. First, pragmatics is the study of speaker meaning. Second, pragmatics is the study of contextual meaning. Third pragmatics is the study of how communication gets more than is said. The last, the pragmatics study of expression of relative distance.

The first speech was conveyed by United Kingdom nationals, philosopher John L. Austin, who was then speaking in 1955 at Harvard University and published in 1962 under the title How To Do Things With Words. However, the theory of speech act itself is more introduced by Searle said that in daily life, there are at least

\footnotetext{
* Corresponding Author.

E-mail Addreses: latifah.tribudiasih@gmail.com (L. T. Budiadih), andayani@staff.uns.ac.id (Andayani), mamad_r76@staff.uns.ac.id (M. Rohmadi)
} 
three types of speech acts. He further said that speech acts divided into three types, namely locution (locutionary act), ilocution (illocutionary act), and perlocution (perlocutionary act) (Searle, 1969).

Handayani (2016) quoted Searle statement that speech acts are divided into three kinds, those are locutionary acts, illocutionary acts, and perlocutionary acts. On the other hand, Isnawati et al. (2015) stated that "in uttering a sentence, a speaker is generally involved in three different acts: "locutionary act, illocutionary act, and perlocutionary act". The three kinds of speech acts in the actual language usage in the community are locutionary acts, illocutionary acts, and perlocutionary acts. This means that when people talk, they use the language to accomplish a variety of functions such as expressing different emotions, starting from opinion or even insulting someone. All of the things described earlier can be said to act speech in the process of speaking. Furthermore, he stated that in the speech acts study, there are three things to consider, namely the language used, the intention of the conversation, and the interaction in the social context

The act of locution or The Act of Saying Something, is a speech act that aims to declare something (Wijana, 1996). The act of illocution is a speech act aimed at doing something. On the other hand, perlocution act is a speech act that aims to declare something with the intention to produce certain effects to influence the listener. Sulistyo (2013) states that the speech act is person's ability in using language to convey messages to listener. From the description of the speech acts of some experts, it can be inferred that the speech act is person's skill in spoken language with the aim to convey messages to the listener by paying attention to the context of the speech. Speech acts are divided into three, namely locution, illocution, and perlocution.

The development of Indonesian Language learners in the world is improving. This improvement of the foreign speakers who learn Indonesian Language is also proved by the increasing number of students of Indonesian Language that come and study in Indonesia. This can be seen from the improvement of Indonesian Language learners numbers that stated in some of language center and language offices at Indonesian. Grade levels in the Indonesian Language learning, especially in Implementing Technical Unit Languages in the Sebelas Maret University, are three levels, those are basic level or a beginner, intermediate or moderate levels, and advanced. In each of these grade levels there is a wide variety of language mastery by students.

Ability and mastery of the student is always increasing. On a basic level, students are still experiencing difficulty in speaking Indonesia either by oral or writing. Students at all grades have never heard or known the language of Indonesia in their country. But at the next levels, students have become accustomed to using the language of Indonesia. Even in everyday life outside the classroom, the students often use Indonesia language to communicate, especially with the people of Indonesia. It signifies that the student has a very positive attitude towards learning Indonesian Language.

Indirectly, the foreign student is the second language learner. Learning a second language is the implication of the mother tongue acquisition (Brown, 1994). Further, Brown gave the seven principles of learning B2 namely: (1) practicing second language; (2) imitating the second language activity; (3) miming the second language from sounds to sentences; (4) starting the activities of listening, speaking, reading, and writing; (5) ordering the language learning naturally from the listening, speaking, reading and writing; (6) learning language without translating, and (7) using the second language in a simple way to the complex one. In this case, if you want to master a second language, then the simplest thing is to use it in everyday life from words, sentences from the simple forms to the complex ones. Relating to the above explanation, the writer aims to describe the illocution on the speech acts of foreign students in Learning Indonesian Language especially in the forms of assertive/representative, directive, declaration, commissive, and expressive speech acts in the Indonesian Language Learning.

\section{Research Methods}

The method in this research is a qualitative approach. The qualitative approach is an approach that aims to build knowledge statement based on constructive or perspective - a perspective participatory (Creswell, 2003). This is case study, aiming to delve phenomena of language in a certain time and activities, as well as collecting detailed information using a variety of data collection procedures for cases of that happening. The object of the research was obtained from research data in the form of illocution, namely assertive, directives, declarations, commissives, and expressives Indonesian Language students.

Research data consist of primary data and secondary data. Primary data are the first data obtained, recorded and collected by researchers (Anwar, 2014). Primary Data in this study are obtained directly by researchers through observation and interview against the Indonesian Language teachers, foreign students or Indonesian 
Language learners, and the manager or coordinator of the Indonesian Language in Technical Implementing (UPT) Language Sebelas Maret University. Secondary data are data that are not observed by researchers directly, for instance through other people or documents (Sugiyono, 2015). In this research, secondary data were obtained from researchers documents, photos, and videos in the Indonesian Language learning activities in the form of acts of said locution, illocution, and perlocution by students in Implementing Technical Unit Language Sebelas Maret University. The data source in this research are three, i.e. informant, documents and library studies.

The methods of data collection in this research are observation, interviews, and documentation methods. The validity of the data (content analysis) is a guarantee of stability summary and interpretation of meanings as a result of research (Sutopo, 2002). The validity of the data used in this study i.e. the technique of triangulation, through a triangulation source, triangulation theory and triangulation methods.

\section{Finding and Discussion}

\subsection{Illocution on Speech Acts of Foreign Student in Indonesian Language Learning}

\subsubsection{Assertive}

Assertive or representative is a speech act of stating, proposing, bragging, complaining, expressing opinions, and reporting. Ilyas and Khusni (2012) stated that assertive illocution is "an assertive act counts as an attempt to explain the actual state of affairs comprising phrases used to address a specific idea, proposition or belief. These acts include asserting that, concluding, informing, predicting and reporting". Following assertive illocution is a speech used to convey a particular idea, where the speakers attached to the truth of the proposition expressed or confidence expressed to listeners such as affirming something, informing things, concluding, and reporting something. Assertive illocution found in Indonesian Language learning in Implementing Technical Unit language of the Sebelas Maret University can be seen as follows.

(1) Pg : "Mungkin kamu mau meyakinkan kepada istrimu bahwa kamu seorang suami yang baik?" (Tertawa). "Kamu butuh berapa menit untuk membuat paragraf persuasi, Abdul? Lima belas menit?"

("Maybe you want to convince your wife that you're a good husband?" (Laughs). "How long did you need to make persuasive paragraphs, Abdul? Fifteen minutes?")

A : "Satu jam."

("One hour.")

Pg : "Tidak boleh satu jam. Itu terlalu lama."

("Not more than one hour. It's too long.")

A : "Em, susah ini."

("Em, it's difficult.")

The above speech acts are assertive illocution. Speakers complained about the duties charged to him. It is seen in the speech that when Pg asked A about the time needed for the task and A as foreigners responded to such A question. He is not able to guarantee if he had to complete the task by the time offered by Pg. Assertive illocution produced a report that is visible from A response stating that the task is too difficult if he had only fifteen minutes to do. So, this form of speech act on this speech is complaining against the given task.

(2) N : "Nanti, nanti bisa baca, ya?

("Later, later (you) can read, can't you?")

$\operatorname{Pg} \quad$ : "Tidak bisa baca? Ya tulisan kamu harus bagus. Kalau tidak bagus tidak bisa dibaca".

("Can't read? Yes. Your writing should be good. If it is not good, it can't be read.")

J : "Ibu jawabannya berbeda dengan maksud Num." (Tertawa)

("Mom, your answer is difference from the intention of Num." (Laughs))

Pg : "Lalu apa?"

("Then, what?")

J : "Jadi, Num tanya, kalau presentasi boleh baca apa tidak, begitu."

("So, the question is, may the presentation be read or not?") 
The speech acts produce assertive/representative illocutions. Speakers provide affirmation through the speech. $\mathrm{J}$ as speakers provided affirmation about Pg and Nm. In the speech, Nm asked Pg whether or not it was allowed read in the presentation, but the response is different from the intention of $\mathrm{Pg} \mathrm{Nm}$. J. who knows the meaning of Nm's speech Nm then explained and confirmed the intent of the speech. So, this form of speech acts is said assertive illocution, where speaker $(\mathrm{J})$ gave you discernment towards partners $(\mathrm{Pg})$ about the intent of the speech earlier.

(3) Pg : "Seperti kalimat, bagaimana kamu menulis. Bukan bagaimana kamu penulis. Ya? Di sini ada kata pemanfaatan. Dari kata apa?"

("Like a sentence, how you write. Not how to be author. All right? Here there is the word of utilization. Where did the word come from?")

$\mathrm{Nm}$ : "Manfaat."

("Benefits.")

J $\quad$ : "Tapi huruf $t$ ibu itu seperti huruf $f$ kecil, tidak ada bedanya."

("But letter of t you wrote looks like a small $f$, there is no difference.")

$\mathrm{Nm}$ : (Tersenyum). "Iya."

((Smiles). “Yes.”)

The speech act is assertive illocution. ( $\mathrm{J})$ as a speaker expressed opinions about the handwriting of $(\mathrm{Pg})$. When Pg wrote on the chalkboard, J criticized her about the letter $\mathrm{t}$ which was written as the letter $\mathrm{f}$. Word written is 'utilization', and J noticed that the handwriting on the letters $t$ and $\mathrm{f}$ is similar. Therefore, $\mathrm{J}$ gave an opinion on the writings of the Pg. This form of speech act on this speech is giving opinions about what Pg did. In this case, the inscription Pg on the Board.

\subsubsection{Directives}

Directive is a speech that aims to produce an effect to a listener in the form of an action or has the intention to make a listener to do something. The functions of directive speech acts according to Rahardi (2000) are ordering, commanding, begging, demanding, and advising. Directive illocution is a speech that aims to produce an effect to the listener the form of action or the intention to make the listener to do something. Directive illocution found in Indonesian Language learning is as follows.

(4) Pg : "Tidak bisa. Terlalu lama. Topik kita hari ini adalah persuasi. Persuasi itu meyakinkan agar seseorang percaya. Tapi kamu harus membuat dalam bahasa Indonesia. Berapa? Lima belas menit cukup ya? Nedu, lima belas menit cukup?"

("You can't. (It's) too long. Our topic today is persuasion. Persuasion is convincing someone to believe it. But you have to make it in Indonesian. How long do you need? Fifteen minutes is enough, ok? Nedu, is fifteen minutes enough?")

Nd : Tidak. Satu jam."

("No. One hour.")

The speech act is directive illocution. Speaker asked to the listener whether one hour is enough to complete the task. So, the form of act is said to give effect on the listener $(\mathrm{Pg})$ in order to give more time to the speakers $(\mathrm{Nd})$. The directive act was conducted by $(\mathrm{Pg})$ who asked the $(\mathrm{Nd})$, to answer the question "how long it took to complete the task". The speech was produced by Pg offering Nd who is foreigners about the time it takes to complete the task. The questions produced by Pg have effect on Nd to answer. So, the speech has the directive illocution.

(5) Pg : "Ya, jadi ini tempat untuk mencari hotel online, ya. Situs jasa hotel, mencari hotel. Ok, sekali lagi." (Menayangkan iklan trivago).

("Yeah, so this is the place to find hotels online, is that right? A website to look for a hotel. OK, once again." (Show trivago ads)

B : "Susah!"

("It's difficult!") 


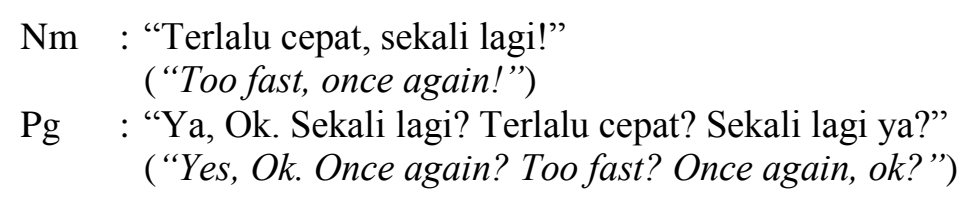

The speech act contains directive illocution. Speakers $(\mathrm{Nm})$ appealed to the listener, $(\mathrm{Pg})$, to repeat the trivago advertisement because Nm felt that Pg showed the advertisement too fast, so he didn't know what is the content of those ads. This speech act is to give influence to the listener $(\mathrm{Pg})$ to do something like what is expected by the speakers $(\mathrm{Nm})$, in this rotating advertising trivago. When $\mathrm{Nm}$ responded by saying that the ads is too fast, he actually asked/begged $(\mathrm{Pg})$ to repeat the playback of those ads and it was fulfilled by listener $(\mathrm{Pg})$.

\subsubsection{Declarations}

Declaration is a speech that falls into the category of a very specific act of saying such as firing, punishing, and hiring. This speech act is intended to create things such as status, circumstances and so forth from the speakers to the said partner (Yule, 1996). Illocution is not found in declarative learning Indonesian Language. Illocution is very special, so it is not found in the form of declarative Indonesian Language learning on illocution.

\subsubsection{Commissives}

Comissive act is a speech act where the speakers attached to an action in the future. These commissive act includes promising, offering, and swearing (Rahardi, 2000). Commissive illocution found in the Indonesian Language learning is as follows.

(6) Pg : "Termasuk kamu. Saya tahu kok." (Tertawa). "Num, ini sudah keempat kamu tadi bilang maju yang ketiga?"

("Including you. I know that." (Laughs). "Num, this is already the fourth, you told me that you wanted to be the third?")

$\mathrm{Nm}$ : "Tapi aku mau yang terakhir." (Tertawa)

("But I wanted to be the last." (laughs))

Pg : "Tadi ketiga, terus keempat, sekarang terakhir?" (Tertawa).

("You said the third, then the fourth, and now the last?" (Laughs))

The speech act is commissive illocution. Speakers promised listener last time after presentation to his friends. So, this form of speech acts is promising something. Speakers $(\mathrm{Nm})$ tied things with listener $(\mathrm{Pg})$ to do something on the future. It is apparent from the speech that $\mathrm{Nm}$ promised to present on the last. It means that $\mathrm{Nm}$ promised to present after all her friend finished the presentation.

(7) Pg : "Num, ibu pikir pas kamu masak itu kamu mau masakin buat ibu tetapi ternyata bukan." ("Num, I thought you cooked for me but you didn't.")

$\mathrm{Nm}$ : "Oh, bukan. Kalau ibu lain waktu."

("Oh, it didn't. Next time, mom.")

The speech act has commissive illocution. Speakers $(\mathrm{Nm})$ promised something to the listener $(\mathrm{Pg})$, that is tied to something in the future. Pg gave a statement addressed to Nm about the cuisine. PG thought that Nm would provide certain dishes to Pg. Speakers $(\mathrm{Nm})$ responded by promising that she would fill out the Pg's request but at another time. In this case, Nm promised something to Pg. Nm is bound to do something in the future. So, this form of speech acts contained commissive illocution functioning as promising something in the future.

\subsubsection{Expressives}

Expressive is a speech act which has the function as a disclosure of psychological attitude of the speaker toward the state implied in the illocution. The action to express this expressive attitude according to Rahardi (2000) is like to say thank you, congratulate, apologize, blame, praise, and say condolences. Expressive Illocution found in learning Indonesian Language in Implementing Technical Unit Language of the Sebelas Maret University is as follows. 
(8) J

: "Ibu, hari ini saya membawa teman. Dia kuliah di Universitas Padjajaran. Maafkan saya terlalu sering membawa teman ke kelas."

("Mom, to day I bring a friend. He is studying at Padjajaran University. Forgive me to often bring friends into the classroom.")

Pg : "Tidak apa-apa. Bawa saja temanmu biar bisa belajar bahasa Indonesia."

("It's okay. Just bring your friend to learn Indonesian.")

The speech act contains expressive illocution. Speaker apologized to both partners (Pg) because the speakers brought his friend to follow the teaching and learning activities in the classroom. So, the form of act is categorized as the apology. Speakers $(\mathrm{J})$ apologizes to $(\mathrm{Pg})$, with the hope the $(\mathrm{Pg})$ forgave and let him bring a friend $(\mathrm{J})$ to follow the teaching and learning activities. So, the form of act is categorized apology or expressive.

(9) M : "Mau makan. Kamu mau ikut?" ("will eat. You want to join?")

$\mathrm{Nm}$ : "Tidak, terima kasih. Tadi sudah sarapan. Ini masih kenyang." ("No, thank you. I've had breakfast. I've not been hungry.")

The speech act contains expressive illocution. Speakers $(\mathrm{Nm})$ thanked the partners $(\mathrm{M})$ because he offered to eat together. (M) offered $(\mathrm{Nm})$ to eat together, and $(\mathrm{Nm})$ responded politely. Speakers answered questions using expressive speech act i.e. grateful because it already offered to eat together. the speakers explained that he had breakfast and he had not been hungry. So, this form of speech act is expressive.

\subsection{Discussion of This Research with Other Research}

Research on speech acts by Ariff (2013) emphasizes more on how speech acts occur in a conversation and relates them to different cultural backgrounds. The similarity of the research with this research is on speech acts. This research is more specific about the form of illocutionary acts conducted by students, whereas the research analyzes students' speech when making an agreement and body expression from men and women when making such an agreement.

Research on speech acts has been done by Suhirman (2016), in the journal IJOLTL with the title "Speech Acts in Psycholinguistics Classes Setting in Postgraduate Program". The study outlines what type of follow up utterances that occurred in class Psycholinguistics graduate program. Data are utterances resulted from an instructor/lecturer and students during the discussion in the classroom. Findings from research are the use of three types of acts, namely locution, illocution and also perlocution. In contrast to these studies, this research focused on the acts of illocution, and only speech acts of the foreign students. The utterances produced by instructors or teachers were not covered in the study.

Research conducted by Pradita (2014) describe the use of a speech acts in the film Habibi-Ainun. The findings in the study mentioned that the speech is made up of the direct speech, indirect speech, representative, commissive, directive, and expressive functions. The equation with this research is about research purposes i.e. describing acts of illocution. In addition, the study also did not find illocution in the form of declaratives. It becomes the equation between such research with this research. However, in the study subjects were analyzed in the form of film Habibi-Ainun, while the study was about the speech acts of foreign students in learning the Indonesian Language.

Research on the speech acts by Zayed (2014), discuss follow up on the use of the form of greeting, asking, thanking, apologizing, and praising. The point of this research is that in using utterances during the ongoing learning, teachers used the speech better at giving, requesting, and saying a thank than using speech while apologizing and praising. Unlike the speech that is made by students, this research shows that students are better at using the utterances of greetings from on the type of speech acts. The difference with this research is that in the subject utterances are examined, the research was more focused on acts of said illocution foreign students, while such research only describes the use of greeting, asking, thanking, apologizing, and praising.

Umaroh (2017), in his research, The Dominance of Illocution and Perlocution in the Transaction of Buying and Selling, mentions that the use of illocution and perlocution in the transaction of buying and selling in the market the traditional Johar Semarang is more dominant. It is influenced by the background of research that generates a lot of speech due to this heteroginity. The research is similar to this research that is about illocution. 
However, the study also describes the use of perlocution speech, whereas this study only focused on the illocution. This research is located in Johar Traditional Market, while the research is located in Language Technical Service Unit with the subject of research of foreign students

Research on speech acts has also been done by Hikmah (2015). This study describes the apologies used by the Javanese by using English. While for the subjects studied were the Javanese with age between 25 to 30 . The results showed that there are four types of speech acts, namely representative, directive, commissive, and expressive. The difference between the study and this research lies in the subject under study. If in the study subjects are an age of about 25 to 30, this study does not use age restrictions. There are similarities between the research and this research, namely finding the speech representative (assertive), directive, commissive, and expressive.

\section{Conclusion}

The act of speech illocution aims to state something in order to influence the listener to do something according to what the speaker wants. The act of speaking of the illocution of foreign students found in Indonesian Language learning in Sebelas Maret University is in the form of acts of assertive/representative, directives, commissives, and expressives. In this study the researcher found three data of assertive, in the form of complaining, confirming something, and expressing opinions. Two directive illocution data are asking and pleading. Declarative illocution is not found in this study. Two expressive data are in the form of apologizing and thanking. Thus, the act of speech of the illocution of foreign students is most often found in the act of assertive is complaining, affirmation, and opinion.

\section{Sugesstion}

Researchers hope that this research can contribute to the reader to better understand the act of speech illocution. The researchers also hope that this research can be an additional reference to anyone who is interested, or wants to learn the research act of speech illocution. In addition to that, the researchers hope that there will be other researchers who will continue this research to enrich pragmatic research, especially on the act of speech illocution. The researcher will feel proud if anyone is willing to criticize and comment on the results of this study, so that researchers can improve on this research or for further research.

\section{References}

Anwar, S. (2014). Metodologi Penelitian Bisnis. Jakarta: Salemba Empat.

Ariff, T. Z. (2013). Speech Act of Promising Among Jordanian. International Journal of Humanities and Social Science, ):, III(13), 248-266.

Brown, H. D. (1994). Principles of Language Learning and Teaching. London: Prentice-Hall Inc.

Creswell, J. W. (2003). Research Design: qualitative, quantitative, and method approached. Callifornia: Sage Publication Inc.

Handayani, T. K. (2016). Nilai-nilai Karakter dalam Tindak Tutur Illocution dalam Buku WIR BESUCHEN EINE MOSCHEE. Litera Jurnal Penelitan Bahasa, Sastra, dan Pengajarannya, , XV(2), 306.

Hikmah, I. (2015). Ketika Orang Jawa Meminta Maaf dengan Menggunakan Bahasa Inggris dari Perspektif Tindak Tutur. PAROLE: Jurnal of Linguistics and Educations, V(2), 95-106.

Ilyas, S., \& Khusni, Q. (2012). Facebook Status Updates: A Speech Act Analysis. Journal Academic Research International, , III(2), 501.

Isnawati, F., Anam, S., \& Diana, S. (2015). Speech Acts an Analysis of The Main Character in Shreek Movie Script. Jember: Publika Budaya.

Leech, G. (2011). Prinsip-PrinsipPragmatik (terjemahan M.D.D. Oka). . Jakarta: UI Press.

Pradita, D. J. (2014). An Analysis of Speech Acts in the Conversation Between Habibi and Ainun in the Film Entitled Habibi and Ainun 2012. e-Journal Program Pascasarjana Universitas Pendidikan Ganesha Program Studi Pendidikan Bahasa Inggris(2 ), 1-10. Retrieved june 2017, from http://download.portalgaruda.org/article.php?article=259601\&val=An Analysis of Speech Acts in the Conversation between Habibie and Ainun in the Film Entitled Habibie and Ainun 2012

Rahardi, R. K. (2000). Imperatif Dalam Bahasa Indonesia. Yogyakarta: Duta Wacana University Press. 
Searle, J. (1969). Speech Act An Essay in the Philosophy of Language. Cambridge: Cambridge University Press.

Sugiyono. (2015). Metode Penelitian Pendidikan (Pendekatan Kuantitatif, Kualitatif, dan R\&D). Bandung: Penerbit Alfabeta.

Suhirman, L. (2016). Speech Acts in Psycholinguistics Class Setting in Postgraduate Program. The IJOLTL, I(1), 19-38.

Sulistyo, E. T. (2013). Pragmatik: Suatu Kajian Awal. Surakarta: Sebelas Maret University Press.

Sutopo, H. B. (2002). Metodologi Penelitian Kualitatif. Surakarta: Sebelas Maret University Press.

Umaroh, L. d. (2017). Dominasi Ilokusi dan Perlokusi dalam Transaksi Jual Beli. Lensa: Kajian Kebahasaan, Kesusastraan, dan Budaya,, VII(1), 1-14.

Wijana, I. D. (1996). Dasar-dasar Pragmatik. Yogyakarta: Penerbit Andi.

Yule, G. (1996). Pragmatics. Oxford: Oxford University Press.

Zayed, N. M. (2014). Jourdanian EFL Teachers and Students Practice of Speech Acts in the Classroom". AUE: International Journal on Studies in English Language and Literature (IJSELL),(2), 1-10. 